\title{
Language and Lying in Roxana: the Last of Defoe's Fiction
}

\author{
Okey Goode \\ Humanities, Lewis-Clark State College, Lewiston, ID 83501, United States \\ *Corresponding Author: ogoode@lcsc.edu
}

Copyright (C) 2013 Horizon Research Publishing All rights reserved.

\begin{abstract}
Defoe, as religious dissenter and writer of fictions, sought to ally moral pronouncement with mimetic representation of material conditions.His character-narrators typically detail the wicked behavior they are driven to for survival as a prelude to repentance. In his final novel, Roxana, however, Defoe confronts his narrator's exploitation of the gap between the referential language of experience and the "internally persuasive" [Bakhtin] conventional discourse of repentance. Once Roxana dethrones "the sovereignty of an original Text" [Foucault], she manipulates the language of repentance to authorize her self-serving sexual license. Defoe cannot resolve the narrative by her repentance. The implications of the split between speech and act may lead Defoe to recognize the similar disjunction between the allure of his character's adventures and his goal of moral instruction. Unable to ally the truth of human experience with the truth of dissenting repentance while ensuring that "the Fable is always made for the Moral" [Defoe], he abandons fiction.
\end{abstract}

Keywords Defoe, Roxana, Lying

\section{Introduction}

Like Swift, Defoe was concerned with the relationship of words and things, attentive to the classical distinction between res et verba that underlies much of eighteenth-century literature, as in Pope's dictum that "the sound must seem an echo to the sense," Richardson's attempt to capture the moment in Pamela's letters, Voltaire's testing in Candide of received definitions against the material conditions that the terms designate, and Sterne's games with words and graphic representations of them in Tristram Shandy. Locke, in his "Epistle to the Reader" in An Essay Concerning Human Understanding, recognizes errors of thought arising from abstract language and realizes that "it is not everyone, nor perhaps anyone, who is so careful of his language as to use no word till he views in his mind the precise determined idea which he resolves to make it the sign of" [1, p. 243].Swift depicts the non-verbal projectors of
Lagados carrying their conversation about in sacks, exchanging ideas literally by unpacking their word-hoard, a satire that

plainly defines the gap between the recalcitrant thing itself and the infinitely portable, malleable words for it.

Whereas Swift's satire explores the concrete and logical limits of language, Defoe's fiction, with its "Foundation . . . laid in the Truth of Fact," as he says in the preface to Roxana [2], seeks to embody in words the spirit that uses them - the Word made flesh. As a dissenter, however, Defoe is steeped in the notion of human fallibility and deceit. He notes in The Wickedness of a Disregard to Oaths (1723) [3, p.110] the "Impossibility to us of knowing the secrets of one anothers Hearts" and laments that "Words . . . do not necessarily convey the true sentiment of man's Mind." Verbal unreliability proves problematic in Defoe's final novel, Roxana, which appeared a year later, because his heroine's continual lying and disguise exploits the dissociation between res et verba that haunts Defoe.

\section{Methodology}

The discussion proceeds by textual analysis of Roxana, informed by genre theory, narratology and reception theory, and the philosophical and religious environment of and in the novel as represented in nonliterary texts by Defoe and others Such analysis expands our conceptions of Defoe, narrative, eighteenth-century culture, and our own stance as readers.

\section{Results}

Both authorial and character voices reveal unresolved practical and spiritual conflicts. Defoe's recognition of the potential irreconcilability of his didactic design with the mimetic/generic demands of narrative authenticity in Roxana, as well as the instability of the text as novel/confession/criminal biography/history/exemplum/document of material culture, accounts in part for the end of Defoe's novel writing. 


\section{Discussion}

George Starr [4] has shown that much of Roxanna's language is drawn from the tradition of spiritual autobiography, and Defoe provides his heroine with an upbringing that would acquaint her with the precepts and vocabulary of dissenting religion. She and her Huguenot parents flee to England to escape persecution by French Catholicism, not seeking simply to improve their business opportunities as her father accuses other refugees of doing but specifically "for Conscience" [2, p .6]. She acknowledges her "virtuous education" [p. 201] and repeatedly evinces it in allusions to "Job's three Comforters," the "pitiful women of Jerusalem," "the hand-writing on the Wall" [pp. 17, 18, 259]. She also paraphrases Proverbs to lament that conscience is "a Dart struck into the Liver . . . a secret Hell within" [p. 260]. Such moral reflection is a hallmark of Defoe's novels but troubling because of its distance from character acts. Roxana early equates being virtuous with using Biblical language. Gary Hentzi [5, p. 193] remarks on Defoe's related appropriation of forms in his novels that "the conversion scene ... [is] a traditional generic paradigm that has been partially emptied of content and put to new use as a saving convention, which allows Defoe to distance himself from the impulse that has driven his narrative ... and substitute a less disturbing logic of the wish fulfillment." The repentant ending, however, whether it is "wish fulfillment" or not, escapes both character and author this time.

The novel's Preface cautions that Roxana does not "recommend her Conduct, or indeed, any Part of it, except her Repentance to our Imitation." Defoe offers the conventional appeal to the instructive value of his fiction to "discourage and expose" the "vicious Mind" [p. 2]. Roxana herself says well into the narrative, "I have look' $d$ back upon these things with Eyes unpossess'd with Crime" [p. 79].Such statements indicate a design similar to that in Moll Flanders: a seemingly authentic criminal autobiography accurately representing the seamy side of life, including the necessity of survival and the allure of opulence and sensuality, all pointed toward the value of self-sufficiency and the tenuously related necessity of repenting. Persuading the audience of the errors of $\sin$ and the value of repentance and spiritual awakening requires Defoe to convey psychological states and religious emotions through language that offers the same lure to abstraction that Locke warns against. Such narrative and ethical tensions are apparent in all of Defoe's novels, but the gap between Roxana's behavior and her verbal self-representation, between material experience and spiritual discourse, enacts Defoe's authorial struggle to reconcile reformative intention, which is the signified, the thing to be realized, with mimetic execution and the variably affective signifiers of intangible words. His narrative means threaten to corrupt his authorial ends.

Roxana concludes far differently than does Moll Flanders, for the heroine's old ways continue beyond the end of her narrative. She does not look back on her misdeeds from the fold of grace. Instead, her narrative stops with her still lying to her virtuous husband and being at least complicit in her daughter's murder. Far from writing from a safe haven, she abandons her story on the brink of an unrevealed "dreadful Course of calamities" [p. 329] that, as it has occurred in her fictive past, has presumably shaped the preceding narrative.

Roxana fully describes her deceptive acts, even revealing her own manner of self-deception. Abandoned by her first husband, she initially resists her landlord's sexual overtures because "I knew he could not like me the better for doing anything that was below a Woman of Honesty and Good manners to do," and accepts that "Without question, a Woman ought rather to die, than to prostitute her Virtue"[pp. 34, 29]. Sixteen years later this tenacity will be meat for Richardson's Pamela, but Defoe and Roxana know that hunger is a legitimate temptation. After she recognizes the economic wisdom of surrendering to the landlord, she maintains the virtue of submission by claiming that, as a woman "furnish'd with Gratitude and just Principles" [p. 35], it is her moral obligation to repay her debts to him. It seems a narrative inconsistency when she reverses her stance and tells her servant, Amy, "[I]f I yield, "tis vain to mince the Matter, I am a Whore" [p. 40], but her extreme self-condemnation lays the groundwork for an alternative rationale for submission: whores are not women struggling with virtue but women already fallen. She poses her choice in dualistic terms. As a "whore" she has no virtue to lose; yet retaining her virtue is unreasonably self-destructive: "I had been happy, 'tho I had perished of meer Hunger" [p. 29]. Either choice invalidates resistance. Verbal condemnation permits physical liberation

She refines this subtle verbal tactic to countenance her later liaison with a prince: "[T]o be call'd handsome, the finest Woman in France, and to be treated as a Woman fit for the Bed of a Prince; these are Things, a Woman must have no Vanity in her, nay, no Corruption in her, that is not overcome by it." The words "Vanity" and "Corruption" are especially liberating terms, for they echo the dissenters' emphasis on original sin and ironically afford a religious indulgence for her Fall: virtue is unattainable by mere woman: "I . . . told his Highness . . . that no Virtue was Proof against him, except such, as was able too, to suffer Martyrdom . . . so much Greatness wou'd have conquer'd a Saint" [pp. 64-65]. Her argument is strikingly similar to another religious renegade's rationale for pursuing his desires. Marlowe's Doctor Faustus reads his Bible and reasons,

The reward of sin is death? That's hard.

....

If we say that we have no $\sin$

We deceive ourselves, and there's no truth in us.

Why then belike we must sin,

And so consequently die.

.....

What doctrine call you this? Che sara, sara, What will be, shall be? Divinity, adieu! 
Michel Foucault [6, p. 41] recognizes bad faith in such textual free dealing: "There can be no commentary unless, below the text one is reading and deciphering, there runs the sovereignty of an original Text." Like Faustus, Roxana dethrones her original text.

The source of Roxana's dual consciousness is her distinction between external behavior and internal reflection. After moralizing on the loss of virtue to her landlord and concluding that "a Woman ought rather to die," she continues abruptly, "But to return to my Story" [p. 29]. Such superficial transitions are common to eighteenth-century novels, but it is significant for an understanding of Roxana's ambivalent perspective that she labels her moralistic comments "meer Talk" [p. 92]. The word "mere" functions paradoxically, meaning in different situations "nothing less than, entirely" (for which the $O E D$ cites Defoe as example) or "nothing more than, only." When Roxana asserts that her beauty is unembellished, she claims it is "the meer [entire] work of Nature" [p. 72]. In a storm at sea, she fearfully confesses to "the meer [nothing less than] Apprehensions of Death" (p. 128). Unlike beauty and fear, however, materially and experientially based, words are only "meer Talk." Because she accepts spiritual examination and self-condemnation as merely words, she achieves what Mikhail Bakhtin [7, p. 345] describes as an "internally persuasive discourse" which is of "decisive significance in the evolution of an individual consciousness." This interior discourse becomes "entirely" physically liberating. The language she reserves for practical, external situations, the language relating to her survival and body-typically seduction and lies-produces "nothing less than" tangible effects, while the language of repentance, of psychological states, produces "nothing more than" verbal abstraction. As Roxana grows aware of the split between words and actions, she increasingly manipulates the familiar speech of spiritual self-examination to create an "internally persuasive" spiritual consciousness for herself that perversely authorizes her external behavior.

Roxana consciously exploits this disjunction between words and actions when she privileges her narration of event by abandoning "loose Reflections" for "outward Appearance" [p. 49], which becomes her only measure of truth. Her obsession with the corporeal is established in one of the novel's most powerful and literal scenes. To prove that her beauty is entirely natural, unenhanced by cosmetics (as if to assert a personal identity amid her welter of disguises), she washes her face before the prince, remarking of her proof, "This was, indeed, more than Satisfaction, that is to say, than Believing; for it was an undeniable Demonstration" [pp. 72-73]. Later, during a storm at sea, she identifies herself as one of those "that understood nothing but just what we saw before us" [p. 123]. Her preference for seeing over believing further invalidates words and, paradoxically, makes moral discourse more acceptable because powerless.

Her conscience - indeed, her sense of a soul — exists only in words; her body, her economic situation, and sexual partners are tangible. She finds that conscience can be satisfied by speaking repentance and confessing guilt, which frees her to indulge in any activity required by physical circumstance. She seems to discover a parodic version of the Biblical dictum, "Ye shall know the truth, and the truth shall make you free" [John 8:32], and pays for her sins with, literally, lingua franca. She accordingly unleashes a flood of verbal self-reproach, self-revelation, and good intentions:

All this while ... I had such a constant Terror upon my Mind, as gave me every now and then very terrible Shocks.

I was Hag-ridden with Frights, and terrible things, form'd merely [i.e., "only"] in the Imagination.

I . . look'd back on former things with Detestation . . . those Reflections began to prey upon my Comforts . . . They might be said to have gnaw'd a Hole in my Heart before but now they made a Hole quite thro' it. [pp. 260, 264]

Significantly in this last context, Starr [4, p. 6n] has noted the prevalence of heart references in conversion narratives and quotes a 1669 example which urges the necessity of "an heart-anatomy" in the way to repentance. Roxana, indeed, has deftly performed "heart-anatomy" by excising her heart entirely to make her behavior palatable. She makes explicit the negligible impact of reflective discourse by identifying it as rote speech: "Some very good Reflections offer'd themselves upon this Head"; yet she "spent half an Hour in these Extravagences, and brought nothing out of them" [pp. 297, 298]. She marks the distance of her internal voice from her real interest with such tags as "But to return to my story" and "But I am not to preach" [pp. 29, 48-49].

The absolution she achieves through self-castigation relates to the question of authorial intention and narrative effect, or reader response, the tangible accomplishment Defoe aimed at through his words. John Bunyan, Defoe's near contemporary and fellow Dissenter, takes care in Pilgrim's Progress to explain that he has "used Similitudes" [1678 title page], that the story is a parable in good Biblical fashion, and he shows through such allegorical characters as Talkative that to talk the talk but not walk the walk is to be self-deceived. Defoe's opposite assertion of authenticity (the "referential language" that since Ian Watt's Rise of the Novel [8] has been held Defoe's distinguishing characteristic) creates an illusory bond between words and the things they signify. If Roxana's reflections enable rather than restrict her libertinism, might not her graphic narrative invite rather than dissuade libidinous reactions from the audience? Defoe raises that issue in the Preface: "When Vice is painted in its Low-priz'd Colours, 'tis not to make People in love with it, but to expose it; and if the Reader makes a wrong Use of the Figures, the Wickedness is his own" [p. 2].As Defoe's more subtle spiritual descendant Nathaniel Hawthorne recognized, the accusation and chastisement of sin affords its own provocative pleasures, as it does in "Young Goodman Brown" for "the constable, when he lashed the Quaker woman so smartly through the streets of Salem." Roxana's language may not only placate her conscience but provide vicarious indulgence for Defoe's dissenting readers just as his 
characters' accumulation and inventory of property-regardless of how acquired-surely enacts their dreams.

Roxana's self-chastisement degrades and humiliates her despised but provocative way of life. "Pornography" means literally "writing about harlots," and Roxana insists repeatedly that she is one. Her litany of sexual misbehavior is like dirty talk between lovers, a reveling in forbidden roles. Listen:

I am ... [one of] the most Worthless Creatures ... I should be carress'd . . . for the Honour of having the scandalous use of my Prostituted Body, common before to .... Inferiours.

I was sure, the Queen of Whores.

He had in his Arms a She-Devil [pp. 74, 82, 301]

Again there are echoes of Doctor Faustus: 'But Faustus' offense can ne'er be pardoned: the serpent that tempted Eve may be saved, but not Faustus" [5.2.41]. Both present themselves as more than mere sinners, as very devils. One scene transcends the aural thrill of mere talk for nothing less than the voyeuristic thrill of an erotic stage show as Roxana prostitutes her servant Amy:

Nay, you Whore, says I, you said, if I wou'd put you to-bed [with their landlord], you wou'd with all your Heart; and with that, I sat her down, pull'd off her Stockings and Shooes, and all her Cloaths, Piece by Piece, and led her to Bed with him ... She pull'd back a little, would not let me pull off her Cloaths at first, but it was hot Weather, and she had not many Cloaths on . . . so I fairly stript her, and then threw open the Bed, and thrust her in. [p. 46]

Amy's conscientious reluctance is no match for the tangible "hot Weather" and the physicality of Roxana as she "fairly stript her." Melinda Snow [9, p. 528] observes that putting Amy to bed with the landlord is "a terrifying argument to the self. It is as if Roxana must convince herself that she is a whore." After engineering Amy's debauch, she confesses - or boasts - "I was fit for any Wickedness" [p. 44]. Such condemnation coming from beyond the veil of repentance is an understandable heaping of abuse on renounced behavior, the reformed sinner's intensification of the evil overcome by grace, and is common to spiritual autobiography; but Roxana does not repent. Her vicious self-portrait of a woman incapable of virtue grants her sexual license.

Defoe himself seems allured by the behavior he condemns in his prefatory summary of Roxana's life:

It is true, She met with unexpected success in all her wicked Courses; but even in the highest Elevations of her Prosperity ... the Pleasure of her wickedness was not worth the Repentance . . . all the Satisfaction she had, all the Joy in the View of her Prosperity, no, nor all the Wealth she rowl'd in: the Gayety of her Appearance: the Equipages, and the Honours, she was attended with, cou'd quiet her mind. [p. 2]

Mingled with the goal of instruction is a rich catalog of pleasures that unbalances the warning and negates the condemnation. The interdependence of chastisement and sin, intention and act, becomes disturbingly clear in parallel scenes. When Amy urges the murder of Roxana's daughter to preserve her mistress's disguise, Roxana replies, "Why, you ought to be hang'd. . . . for having resolv'd . . . is doing it" [p. 273]. By this logic-conveniently supported by scripture - to think evil is to do it; therefore, sinful thoughts may as well be acted upon: the moment of resistance is past. When it comes to virtuous action, on the other hand, thought doesn't impose on behavior. She has already decided that "Conscience left off speaking, where it could not be heard," so when she ponders, "What was I a Whore for now?" she discovers that the concern "made no Impressions upon me of that kind which might be expected from a Reflection of so important a Nature, and which had so much of Substance and Seriousness in it" [pp. 201, 203]. The very insubstantiality of the merely moral "substance" of the question allows Roxana to ask it without altering her behavior. Furthermore, as "having resolv'd . . . is doing it," simply thinking of virtue suffices.

Intention and effect, words and actions are the oppositions Roxana and Defoe face. Roxana finds a way to achieve both by divorcing them. Defoe seems debilitated by the split; unlike Roxana, his aim is to reveal and resolve the gap between words and deeds, not exploit it (one of his rare efforts at Swiftian ironic juggling of words and meaning, The Shortest Way with Dissenters in 1702, was misread as serious argument by both dissenters and High Church Tories). Snow [9, p. 533] recognizes that "how to read Roxana becomes a significant hermeneutical question. What does the narrative mean? Does it deconstruct itself by presenting contrary arguments?" and David Durant [10, p. 235] sees in the disconnect an "implicit condemnation of the amorality of fiction [that] may help explain why it is Defoe's last novel." Defoe's suspicion of fiction's amorality, or immorality, may also help explain why he turns immediately to nonfictional pirate biographies with his General History of the Pyrates (1724): for pirates, the opportunity for disguise through verbal performance of repentance is eliminated by the material resolution of hanging. Defoe says explicitly in the preface to Serious Reflections . . . of Robinson Crusoe (1720) [11, p. 259], "As the Design of every Thing is said to be first in the Intention, and last in the Execution . . . so . . . the Fable is always made for the Moral." This theory launched four years before Roxana seems finally to run aground. In the same preface [12, p. 147], he explains that "this supplying a story by invention . . . is a sort of lying that makes a great hole in the heart" - the same confessional phrase he allots to Roxana. For her, however, that hole caused by empty words is filled by allegiance to things.

Defoe explains in The Family Instructor (1715) [4, p. 42] that repentance "must proceed not only from a Fear of eternal Punishment, but from the Hatred of Sin, for its own evil Nature"; however, as a result of Roxana's bad faith in using the language of condemnation and repentance, when she reaches the turning point she cannot bridge the gap to the experience of repentance:

Sometimes the Wonders of my present Circumstances 
wou'd work upon me, and I shou'd have some Raptures upon my Soul . . . but this was a Flight too high for me; I was not come to that Repentance that is rais'd from a Sense of Heaven's Goodness . . . but it was another and lower kind of Repentance, and rather mov'd by my Fears of Vengeance. [p. 261]

Defoe, with his own narrative "hole in the heart," might well say of this declined resolution, as Roxana does when she refuses the respectability of marriage to a Dutch merchant, "I had a safe Harbour presented, and no Heart to cast-Anchor in it" [p. 162]. Repentance has become only another fraudulent disguise, not an escape.

\section{Conclusion}

In speculating about his law of gravity in Mathematical Principles of Natural Philosophy, Sir Isaac Newton [13, p. 80] - not entirely the mechanistic materialist William Blake took him for-assumed in 1687, when the fictional Roxana was fourteen years old, that the pervasive presence of gravity in matter was a sign that God "is omnipresent not virtually only but also substantially; for virtue cannot exist without substance" (Newton's italics). Roxana shares no such assumption. Her ability to satisfy the intangible demands of word and spirit without a corresponding effect in the world of acts and flesh leads to the bleak non-ending of her narrative: "I was brought so low . . . that my Repentance seem'd to be only the Consequence of my Misery, as my Misery was of my Crime" [p. 330]. The experience of even this transitory repentance is not generated by verbal pronouncement but as a consequence of material forces. If words have no effect on Roxana, why should her abstract moralizing have a stronger effect than her actions on Defoe's readers? Perhaps Defoe's dual allegiance to the truth of human behavior and to the truth of dissenting repentance prevents him from permitting Roxana's reformation. To ally his fiction's words with the reality of both material experience and spiritual truth as he sees it, he cannot lie to save her. Far from achieving the reformatory function that Defoe intended, Roxana ironically reaffirms the distance between words and deeds. Both author and character end by "falling into Gulphs" [2, p. 264] between the two.

\section{REFERENCES}

[1] E. Burtt, ed. The English Philosophers from Bacon to Mill, Random House, New York, 1939.

[2] D. Defoe. Roxana, Oxford University Press, London, 1964.

[3] M. Novak. Realism, Myth, and History in Defoe's Fiction, University of Nebraska Press, Lincoln, 1983.

[4] G. A. Starr. Defoe and Spiritual Autobiography, University of California Press, Berkeley, 1975.

[5] G. Hentzi. Holes in the heart: Moll Flanders, Roxana, and “agreeable crime,” Boundary, Vol.18, No.1, 174-200, 1991.

[6] M. Foucault. The Order of Things: An Archaeology of the Human Sciences, Vintage Books, New York, 1994.

[7] M. Bakhtin. The Dialogic Imagination: Four Essays, University of Texas press, Austin, 1981.

[8] I. Watt. The Rise of the Novel, University of California Press, Berkeley, 1957.

[9] M. Snow. Arguments to the self in Defoe's Roxana, Studies in the Novel, 34, 523-36, 1994.

[10] D. Durant. Roxana's fictions, Studies in the Novel, 13, 225-36, 1981.

[11] D. Defoe. Robinson Crusoe, Norton, New York, 1975.

[12] W. Minto. Daniel Defoe, Macmillan, London, 1902.

[13] R. Grossinger. The Night Sky: The Science and Anthropology of the Stars, Jeremy P. Tarcher, Los Angeles, 1988 